\title{
Estimation of postseismic deformation parameters from continuous GPS data in northern Sumatra after the 2004 Sumatra-Andaman earthquake
}

\author{
Bimar Anugrah • Irwan Meilano • Endra Gunawan • Joni Efendi
}

Received: 8 September 2015/Accepted: 3 November 2015/Published online: 8 December 2015

(C) The Author(s) 2015. This article is published with open access at Springerlink.com

\begin{abstract}
Continuous global positioning system (GPS) in northern Sumatra detected signal of the ongoing physical process of postseismic deformation after the M9.2 2004 Sumatra-Andaman earthquake. We analyze the characteristics of postseismic deformation of the 2004 earthquake based on GPS networks operated by BIG, and the others named AGNeSS, and SuGAr networks located in northern Sumatra. We use a simple analytical logarithmic and exponential function to evaluate the postseismic deformation parameters of the 2004 earthquake. We find that GPS data in northern Sumatra during time periods of 2005-2012 are fit better using the logarithmic function with $\tau \log$ of $104.2 \pm 0.1$ than using the exponential function. Our result clearly indicates that other physical mechanisms of postseismic deformation should be taken into account rather than a single physical mechanism of afterslip only.
\end{abstract}

Keywords The 2004 Sumatra-Andaman earthquake . Continuous GPS data $\cdot$ Logarithmic and exponential functions

\footnotetext{
B. Anugrah · I. Meilano ( $\square)$

Geodesy and Geomatics Engineering, Faculty of Earth Science and Technology, Bandung Institute of Technology, Jl. Ganesa 10, Bandung 40132, Indonesia

e-mail: irwanm@gd.itb.ac.id

E. Gunawan

Graduate Research on Earthquake and Active Tectonics, Faculty

of Earth Science and Technology, Bandung Institute of

Technology, Jl. Ganesa 10, Bandung 40132, Indonesia

J. Efendi

Geospatial Information Agency, Jl. Jakarta-Bogor Km. 46,

Cibinong 16911, Indonesia
}

\section{Introduction}

Indonesia is surrounded by four major plates; they are Eurasian plate, Indo-Australian plate, Pacific plate, and Philippine plate. This complex tectonic condition may cause earthquakes. These earthquakes possibly occur in the area of subduction zones, such as the 2005 M8.7 Nias earthquake (e.g., Kreemer et al. 2006), the 2010 M7.8 Mentawai earthquake (e.g., Hill et al. 2012), the 1994 M7.8 and 2006 M7.8 Java tsunami earthquake (e.g., Bilek and Engdahl 2007), and along the inland faults, such as the 1987 M6.6 Toru earthquake (Sieh and Natawidjaja 2000) and the 2013 M6.1 Aceh earthquake (Ito et al., manuscript in preparation, 2015). One of the active inland fault zones is the Great Sumatran Fault (GSF). GSF, one of the world's greatest fault zones located inland of Sumatra, consists of 20 segments (Sieh and Natawidjaja 2000) starting from the southern Sumatra with a plate movement of $12 \mathrm{~mm} / \mathrm{a}$ (Meilano, Susilo and Gunawan, manuscript in preparation, 2015) to the northern Sumatra with the increasingly rapid movements of $20 \mathrm{~mm} / \mathrm{a}$ (Ito et al. 2012). Historically, magnitude 7 class earthquakes have been occured along GSF (Sieh and Natawidjaja 2000).

One of the large megathrust earthquakes occured due to subduction process between Indo-Australian plate and Eurasian plate was the 26 December 2004 M9.2 SumatraAndaman earthquake (Fig. 1) (e.g., Subarya et al. 2006). According to the geodetic and geological estimation, the continental shelf of Southeast Asia moves independently than Eurasian plate defined as Sundaland block (e.g., Bock et al. 2003). The 2004 Sumatra-Andaman earthquake resulted from devastating tsunami with the lost of more than 280,000 inhabitants (e.g., Sieh 2006). This earthquake is considered as a megathrust earthquake with a longest rupture compared with other earthquakes (Shearer and 


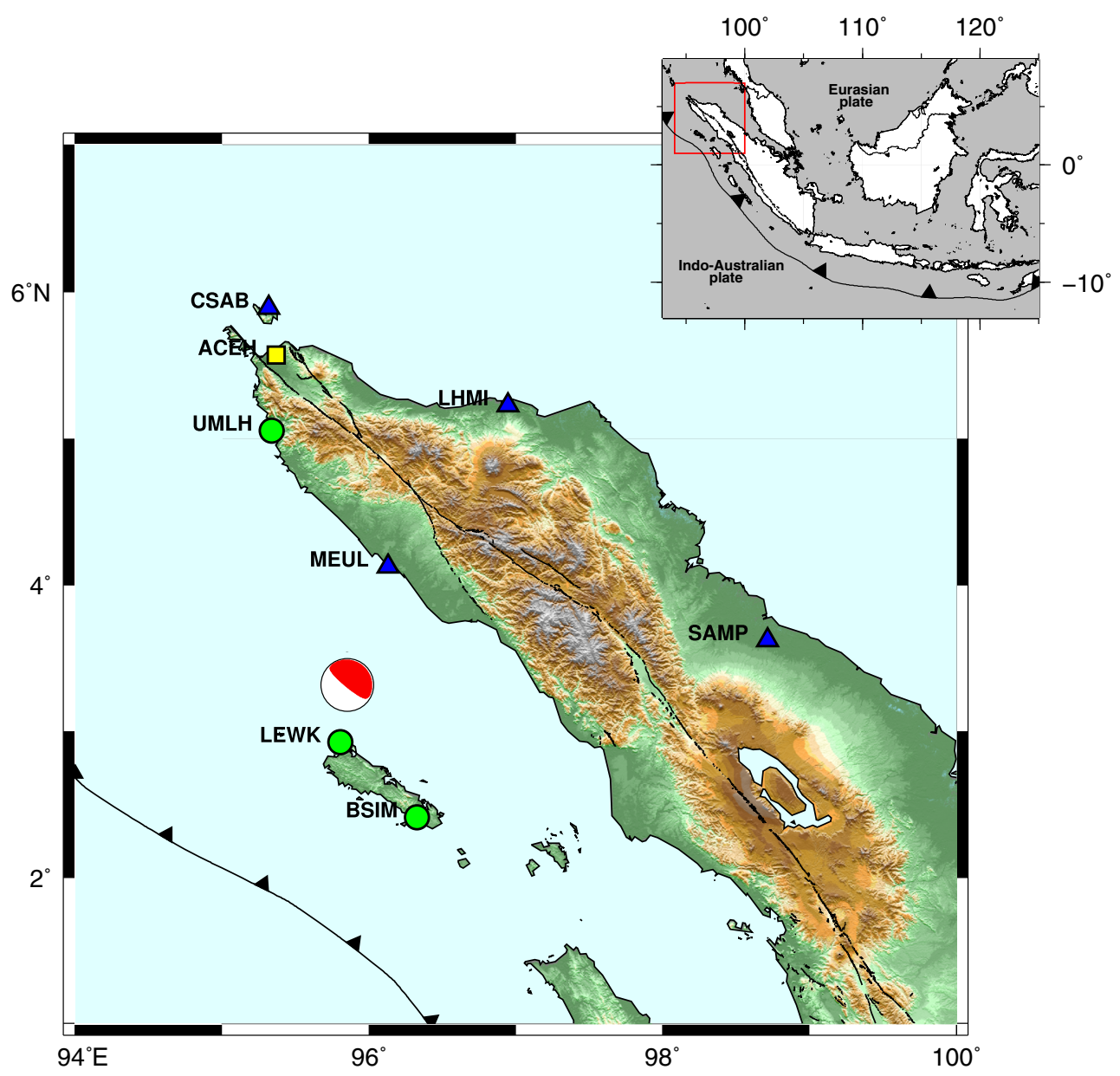

Fig. 1 The distribution of GPS sites used in this study. Blue triangle indicates the GPS sites of BIG, while green circle denotes the GPS site of SuGAr, and yellow square implies the GPS site of AGNeSS. The epicenter of the 2004 Sumatra-Andaman earthquake obtained from USGS catalog. Black lines inland of Sumatra show the location of GSF. Inset shows larger regional setting

Bürgmann 2010). Rupture along the $\sim 1600 \mathrm{~km}$ starts from the epicenter near the island of Simeulue $\left(3.3160^{\circ} \mathrm{N}\right.$, $95.8540^{\circ} \mathrm{E}$ ) and continuously up to the Andaman Islands with a speed of $1 \mathrm{~km} / \mathrm{s}$ (Fujii and Satake 2007). That rupture completed within about $10 \mathrm{~min}$ and be a source of nuisance of sea water volume in which became a devastating tsunami (Chlieh et al. 2007).

After the 2004 Sumatra-Andaman earthquake, governments and institutions of many countries have collaborated together to understand deeply this earthquake. Many researchers have been trying to understand the characteristics of the 2004 Sumatra-Andaman earthquake so that they might determine the further earthquakes occurrence potential as well as analyze and evaluate the disaster mitigation in northern Sumatra. For instance, the cooperation between the universities from Indonesia and Japan resulted in the project of global positioning system (GPS) observation spread across several regions in northern Sumatra. This GPS network named AGNeSS (Aceh GPS Network for the Sumatran Fault System) (Ito et al. 2012; Gunawan et al. 2014). Previous studies suggested that there are ongoing postseismic activities due to the 2004 SumatraAndaman earthquake with the movement of $5-15 \mathrm{~cm}$ per year observed in the Andaman Islands (e.g., Som et al. 2011, 2014), and also in Thailand (e.g., Panet et al. 2010). Furthermore, Gunawan et al. (2014) suggested that postseismic deformation in the long-term period after earthquake occurrences corresponds to viscous flow in the asthenosphere. They showed that contribution of afterslip during one year periods from end of 2005 to end of 2006 corresponds to $\sim 60 \%$ of GPS data displacements.

This study analyzes the continuous GPS data available in northern Sumatra which clearly detect the significant signal of postseismic deformation after the 2004 SumatraAndaman earthquake. We use more new continuous GPS data observed by the network that is installed and maintained by Geospatial Information Agency of Indonesia (BIG) in northern Sumatra. This GPS data is very 
important because it has never been published by any previous researches before. Additionally, this continuous GPS data may capture the ongoing process of postseismic deformation in northern Sumatra after the 2004 SumatraAndaman earthquake. Here, we focus on determining the postseismic deformation parameters of the GPS data time series using simple analytical logarithmic and exponential functions.

\section{Data and method}

Data used in this study are continuous GPS data observed in northern Sumatra. One GPS network is operated by BIG, and the other GPS networks are named AGNeSS, and SuGAr (Sumatran GPS Array). Figure 1 shows the distribution of GPS sites used in this study.

GPS sites of CSAB, LHMI, MEUL, and SAMP were installed and maintained by BIG. Among these sites, SAMP is the oldest one which has been established since 1997. Then, MEUL was constructed in 2008, followed by LHMI in 2010 and CSAB in 2011. ACEH site is part of AGNeSS, has been installed and maintained since 2005 by the collaboration of Nagoya University, Kochi University, Tohoku University, Bandung Institute of Technology, and Syiah Kuala University (Ito et al. 2012). BSIM, LEWK, and UMLH sites are part of SuGAr installed and maintained since 2005 by Earth Observatory of Singapore (EOS) and Indonesian Institute of Sciences (LIPI) (Feng et al. 2015).

Time series of ACEH was published by previous studies (Ito et al. 2012; Gunawan et al. 2014), so we used their result for further analysis. For other sites, we performed GPS data processing using GAMIT 10.5 to obtain daily solutions (Herring et al. 2010). We used three steps to process the data with GAMIT 10.5. First step is data preparation. It means to prepare raw phase and pseudorange data in the form of ASCII X-files, station coordinates in the form of L-file, receiver and antenna information for each site, satellite list and scenario, initial conditions for the satellites orbits in a G-file, satellite and station clock values, control files for the analysis, standard tables to provide lunar/solar ephemerides, the Earth's rotation, geodetic datums, and instrumentation information. Second, creating model of each parameter to solve the phase ambiguity to obtain a preliminary coordinate of each site observation. Third, we fix the preliminary coordinate result to IGS sites such as KIT3, HYDE, COCO, DGAR, IISC, KUNM, CUSV, NTUS, BAKO, XMIS, TNML, TWTF, PIMO, DARW, KARR, YAR2, CNMR, GUAM, TOW2, KOUC, and obtain daily solutions in International Reference Frame (ITRF) 2008 (Altamimi et al. 2011).
In order to make the GPS data much more appropriate for tectonics discussion, we need to use the time series data in the Sundaland block reference frame. So after obtaining daily solutions in ITRF2008, we transformed these time series data to obtain daily solutions in the Sundaland block. We use rotation pole proposed by Simons et al. (2007) with parameters of $49.0^{\circ} \mathrm{N},-94.2^{\circ} \mathrm{E}, 0.336^{\circ} / \mathrm{Ma}$, which is calculated using 28 GPS sites located in South East Asia region. In order to use these parameters correctly, first, we transformed the daily solutions from ITRF2008 into ITRF2000 (Altamimi et al. 2011). Second, we transformed daily solutions from ITRF2000 reference frame into Sundaland block reference frame.

We matched these data based on characteristics of afterslip using logarithmic function (Marone et al. 1991), defined as $u(t)=c+a \ln (1+t / \tau \log )$. We compare the results with other definition of data fit using exponential function (Savage and Prescott 1978), defined as $u(t)=c+a\left(1-\mathrm{e}^{-t / \tau \exp }\right)$. In these functions, $u(t)$ is horizontal component position, $c$ is data offset and $a$ is amplitudes, while $\tau \log$ and $\tau \exp$ are decay time of afterslip for logarithmic function and exponential function. We fit the time series horizontal data to these two functions, and search for the unknown parameters of $c, a, \tau \log$, and $\tau \exp$, respectively.

\section{Result and discussion}

\subsection{Time series analysis}

The daily solutions of GPS data processing were used to analyze and determine the characteristics of each GPS observation site and the quality of observational data distribution. The displacement characteristics of each observation station were then determined by analyzing the time series of the horizontal components in each GPS site that refer to the Sundaland block reference frame. Figure 2 shows the daily solutions of each GPS site in northern Sumatra.

Previous studies suggested that northern Sumatra experience significant coseismic and postseismic deformation of the 12 April 2012 M8.6 Indian Ocean earthquake (e.g., Yadav et al. 2012; Wei et al. 2013; Hill et al. 2015; Han et al. 2015). In addition, GPS data in Java also experienced crustal deformation due to this earthquake (Gunawan et al., manuscript in preparation, 2015). Since our analysis focused on the 2004 Sumatra-Andaman earthquake, we did not use the GPS data after the 2012 earthquake for further analysis as it was clearly influenced by the 2012 earthquake.

During the period of 2005-2012, there were earthquakes adjacent to this regions detected by GPS time series data. These earthquakes were the 28 March 2005 M8.7 Nias 
ACEH

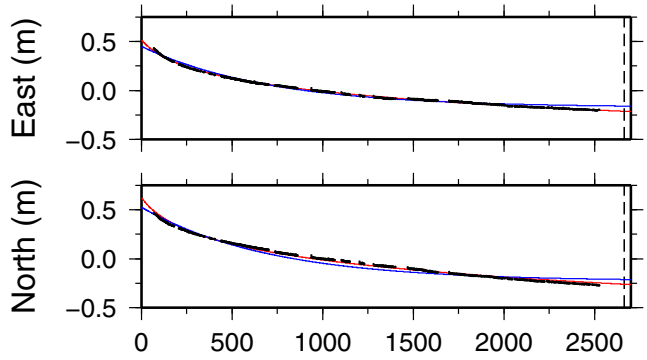

MEUL

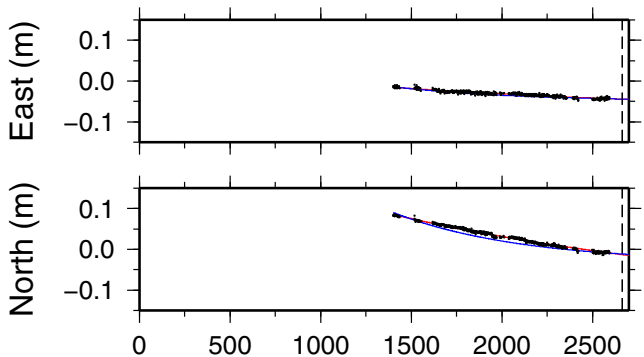

LHMI

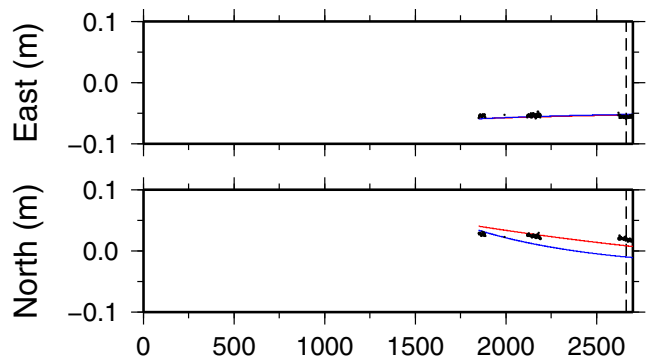

UMLH
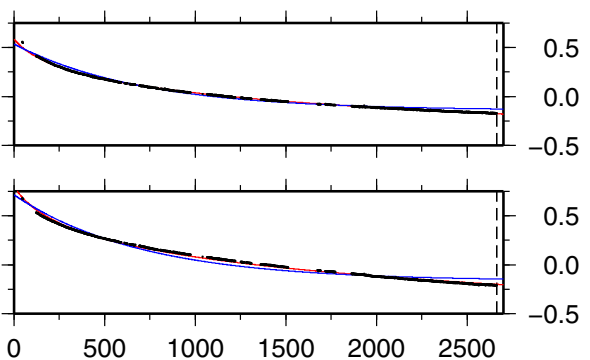

SAMP
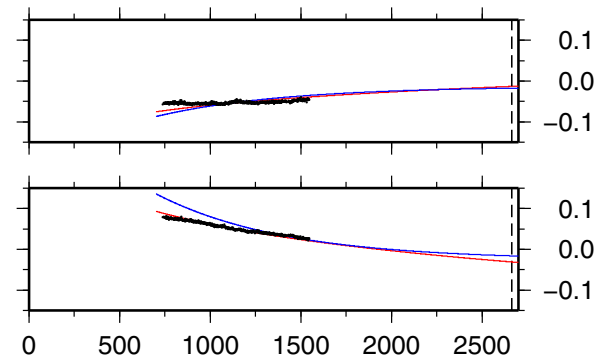

CSAB

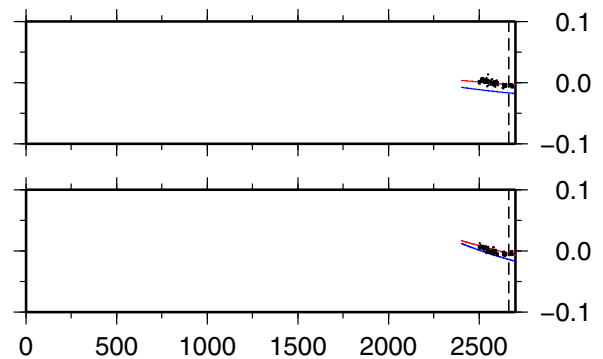

Fig. 2 Time series of GPS sites in northern Sumatra used in this study. Horizontal axis indicates days after the 2004 Sumatra-Andaman earthquake, while vertical axis implies displacements in meter. Vertical dashed lines denote time of the 2012 Indian Ocean earthquake. Solid red lines indicate calculated model based on best-fit parameters of logarithmic function, while solid blue lines are from exponential functions. Black dots represent the GPS time series data

earthquake (e.g., Kreemer et al. 2006), the 20 February 2008 M7.4 Simeuleu earthquake (Sladen et al. 2009), and the 6 April 2010 M7.8 Northern Sumatra earthquake (https://www.iris.edu/hq/files/programs/education_and_ outreach/retm/tm_100406_sumatra/100406_sumatra.pdf, accessed on October 2015).

The significant signal of postseismic deformation of the 2005 Nias earthquake was detected by BSIM and LEWK. Previous studies suggested that significant postseismic deformation of afterslip after the 2005 Nias earthquake occurred at shallow portion of the main rupture at $97^{\circ} \mathrm{E}$, $1^{\circ} \mathrm{N}$ (Hsu et al. 2006; Kreemer et al. 2006). They suggested that afterslip influenced deformation observed by GPS surrounding Nias Island. On the other hand, due to location of GPS sites in northern Sumatra much closer to the rupture of the 2004 Sumatra-Andaman earthquake and much larger magnitude size of this earthquake than the 2005 Nias earthquake, previous studies suggested that GPS data in northern Sumatra are most significantly influenced by the 2004 earthquake (Subarya et al. 2006; Gunawan et al. 2014). That was why BSIM and LEWK would not be used for further analysis.

Similarly to the cases of the 2008 Simeulue earthquake and the 2010 Northern Sumatra earthquake, where location of GPS sites in northern Sumatra was much closer to the rupture of the 2004 Sumatra-Andaman earthquake and much larger magnitude size of the 2004 earthquake than those of the 2008 and 2010 earthquakes. So for MEUL site, we removed only the coseismic displacements of the 2010 earthquake with $-0.0184 \mathrm{~m}$ easting and $0.0385 \mathrm{~m}$ northing, as postseismic deformation, was insignificant compared to the 2004 earthquake. We concluded that in this study, we use only GPS data from ACEH, UMLH, CSAB, SAMP, MEUL, and LHMI. 
Table 1 Postseismic parameters of logarithmic function

\begin{tabular}{lllrlrlrl}
\hline Site & Long $\left({ }^{\circ} \mathrm{E}\right)$ & Lat $\left({ }^{\circ} \mathrm{N}\right)$ & \multicolumn{2}{l}{ Logarithmic terms } & RMS \\
\cline { 3 - 7 } & & & \multicolumn{1}{c}{$c_{\text {east }}(\mathrm{mm})$} & \multicolumn{1}{c}{$c_{\text {north }}(\mathrm{mm})$} & \multicolumn{1}{c}{$a_{\text {east }}(\mathrm{mm})$} & \multicolumn{1}{c}{$a_{\text {north }}(\mathrm{mm})$} & \\
\hline ACEH & 95.36 & 5.56 & $514.2 \pm 0.6$ & $623.8 \pm 3.5$ & $-221.9 \pm 0.6$ & $-269.9 \pm 3.5$ & 10.4 \\
UMLH & 95.33 & 5.05 & $586.0 \pm 0.4$ & $797.5 \pm 2.1$ & $-232.8 \pm 0.4$ & $-304.2 \pm 2.1$ & 8.1 \\
CSAB & 95.31 & 5.89 & $228.6 \pm 0.9$ & $682.1 \pm 4.7$ & $-70.7 \pm 0.9$ & $-209.2 \pm 4.7$ & 4.0 \\
SAMP & 98.71 & 3.62 & $-178.3 \pm 0.4$ & $298.8 \pm 4.6$ & $950.4 \pm 0.4$ & $-100.6 \pm 4.6$ & 6.2 \\
MEUL & 96.13 & 4.12 & $113.0 \pm 0.1$ & $517.2 \pm 2.6$ & $-47.5 \pm 0.1$ & $-161.7 \pm 2.6$ & 2.4 \\
LHMI & 96.94 & 5.22 & $-110.9 \pm 0.1$ & $360.3 \pm 5.6$ & $17.8 \pm 0.1$ & $-92.1 \pm 5.6$ & 4.6 \\
Average & & & & & & & 5.9 \\
\hline
\end{tabular}

\begin{tabular}{|c|c|c|c|c|c|c|c|}
\hline \multirow[t]{2}{*}{ Site } & \multirow{2}{*}{$\begin{array}{l}\text { Long } \\
\left({ }^{\circ} \mathrm{E}\right)\end{array}$} & \multirow{2}{*}{$\begin{array}{l}\text { Lat } \\
\left({ }^{\circ} \mathrm{N}\right)\end{array}$} & \multicolumn{4}{|c|}{ Exponential terms } & \multirow[t]{2}{*}{ RMS } \\
\hline & & & $c_{\text {east }}(\mathrm{mm})$ & $c_{\text {north }}(\mathrm{mm})$ & $a_{\text {east }}(\mathrm{mm})$ & $a_{\text {north }}(\mathrm{mm})$ & \\
\hline ACEH & 95.36 & 5.56 & $449.8 \pm 0.5$ & $217.2 \pm 9.5$ & $-623.8 \pm 0.5$ & $-754.6 \pm 9.5$ & 25.7 \\
\hline UMLH & 95.33 & 5.05 & $534.8 \pm 0.3$ & $713.2 \pm 5.1$ & $-678.0 \pm 0.3$ & $-879.0 \pm 5.1$ & 29.5 \\
\hline CSAB & 95.31 & 5.89 & $857.8 \pm 0.8$ & $246.8 \pm 5.4$ & $-895.0 \pm 0.8$ & $-253.9 \pm 5.4$ & 12.1 \\
\hline SAMP & 98.71 & 3.62 & $-213.1 \pm 0.7$ & $41.2 \pm 14.3$ & $200.1 \pm 0.7$ & $-438.2 \pm 14.3$ & 16.2 \\
\hline MEUL & 96.13 & 4.12 & $213.1 \pm 0.09$ & $858.5 \pm 5.0$ & $-263.4 \pm 0.09$ & $-890.5 \pm 5.05$ & 6.7 \\
\hline LHMI & 96.94 & 5.22 & $-193.1 \pm 0.2$ & $898.5 \pm 8.6$ & $144.4 \pm 0.2$ & $-878.5 \pm 8.6$ & 11.7 \\
\hline Average & & & & & & & 16.9 \\
\hline
\end{tabular}

Table 2 Postseismic parameters of exponential function
Our finding supported previous research, which suggested that afterslip corresponds to early deformation after earthquake occurrences (Gunawan et al. 2014). In this study, we showed a detail result of postseismic parameters of the 2004 SumatraAndaman earthquake. Using a simple analysis model of logarithmic function, we could obtain the ongoing physical mechanisms process after earthquake occurrences exhaustively.

The difference between data fitting to logarithmic and exponential functions was significantly observed and visible during early periods after the 2004 earthquake, especially at ACEH and UMLH sites where early time series data are available (Fig. 2). This indicates that ACEH and UMLH play major role in our analysis. In the longer time series data, discrepancy between logarithmic and exponential functions to fit the data is invisible. Our analysis suggests the importance of maintaining continuous GPS data in prior, during, and after earthquake occurrences for further hazard analysis.

\section{Conclusions}

We show that GPS sites in northern Sumatra clearly detect significant postseismic deformation after the 2004 Sumatra-Andaman earthquake. We conclude that GPS data in northern Sumatra during the period of 2005-2012 are very well matched using logarithmic function with smaller average misfit of $\sim 2.8$ times compared to matching using exponential function. The decay time of postseismic 
deformation of 104.2 days indicates that other mechanisms of postseismic deformation should be taken into account rather than a single physical mechanism of afterslip only.

Acknowledgments This paper benefitted from the constructive comments of two anonymous reviewers. The authors would like to thank Dedi Sunaedi, Euis Rusmiati, GREAT-ITB 2015, and Government of West Java for the support that has been given. This study was partially funded by the PLN APJ of Sukabumi No. 203/060/APJ-SKI/ 2010, Indonesia Endowment Fund for Education (LPDP) No. PRJ1048/LPDP/2015, and the Australian Department of Foreign Affairs and Trade (DFAT) for Graduate Research on Earthquake and Active Tectonics at the Bandung Institute of Technology. We would also like to thank BIG, EOS (Earth Observatory of Singapore), and LIPI (Indonesian Institute of Sciences) that have provided relevant data related to this study. Figures were drawn using GMT software (Wessel et al. 2013).

Open Access This article is distributed under the terms of the Creative Commons Attribution 4.0 International License (http://creative commons.org/licenses/by/4.0/), which permits unrestricted use, distribution, and reproduction in any medium, provided you give appropriate credit to the original author(s) and the source, provide a link to the Creative Commons license, and indicate if changes were made.

\section{References}

Altamimi Z, Collilieux X, Métivier L (2011) ITRF2008: an improved solution of the international terrestrial reference frame. J Geodesy 85(8):457-473

Bilek SL, Engdahl ER (2007) Rupture characterization and aftershock relocations for the 1994 and 2006 tsunami earthquakes in the Java subduction zone. Geophys Res Lett 34(20): 100

Bock Y, Prawirodirdjo L, Genrich JF, Stevens CW, McCaffrey R, Subarya C, Puntodewo SSO, Calais E (2003) Crustal motion in Indonesia from global positioning system measurements. J Geophys Res 108(B8):2367

Chlieh M, Avouac JP, Hjorleifsdottir V, Song TRA, Ji C, Sieh K, Sladen A, Hebert H, Prawirodirdjo L, Bock Y, Galetzka J (2007) Coseismic slip and afterslip of the great $M_{\mathrm{W}} 9.15$ Sumatra-Andaman earthquake of 2004. Bull Seismol Soc Am 97(1A):S152-S173

Feng L, Hill EM, Banerjee P, Hermawan I, Tsang LL, Natawidjaja DH, Suwargadi BW, Sieh K (2015) A unified GPS-based earthquake catalog for the Sumatran plate boundary between 2002 and 2013. J Geophys Res 113:B12406

Fujii Y, Satake K (2007) Tsunami source of the 2004 SumatraAndaman earthquake inferred from tide gauge and satellite data. Bull Seismol Soc Am 97(1A):S192-S207

Gunawan E, Sagiya T, Ito T, Kimata F, Tabei T, Ohta Y, Sugiyanto D (2014) A comprehensive model of postseismic deformation of the 2004 Sumatra-Andaman earthquake deduced from GPS observations in northern Sumatra. J Asian Earth Sci 88:218-229

Han SC, Sauber J, Pollitz F (2015) Coseismic compression/dilatation and viscoelastic uplift/subsidence following the 2012 Indian Ocean earthquakes quantified from satellite gravity observations. Geophys Res Lett 42:3764-3774

Herring TA, King RW, McClusky SC (2010) Documentation of the GAMIT GPS Analysis Software release 10.4. Department of Earth and Planetary Sciences, Massachusetts Institute of Technology, Cambridge, Massachusetts

Hill EM, Borrero JC, Huang Z, Qiu Q, Banerjee P, Natawidjaja DH, Elosegui P, Fritz HM, Suwargadi BW, Pranantyo IR, Li L, Macpherson KA, Skanavis V, Synolakis CE, Sieh K (2012) The $2010 M_{\mathrm{W}} 7.8$ Mentawai earthquake: very shallow source of a rare tsunami earthquake determined from tsunami field survey and near field GPS data. J Geophys Res 117(B6):55

Hill EM, Yue H, Barbot S, Lay T, Tapponnier P, Hermawan I, Judith Hubbard J, Banerjee P, Feng L, Natawidjaja D, Sieh K (2015) The $2012 M_{\mathrm{W}} 8.6$ Wharton Basin sequence: a cascade of great earthquakes generated by near-orthogonal, young, oceanic mantle faults. J Geophys Res: Solid Earth

Hsu YJ, Simons M, Avouac JP, Galetzka J, Sieh K, Chlieh M, Natawidjaja D, Prawirodirdjo L, Bock Y (2006) Frictional afterslip following the 2005 Nias-Simeulue earthquake, Sumatra. Science 312(5782):1921-1926

Ito T, Gunawan E, Kimata F, Tabei T, Simons M, Meilano I, Agustam, Ohta Y, Nurdin I, Sugiyanto D (2012) Isolating alongstrike variations in the depth extent of shallow creep and fault locking on the northern Great Sumatran Fault. J Geophys Res: Solid Earth (1978-2012) 117(B6)

Kreemer C, Blewitt G, Maerten F (2006) Co- and postseismic deformation of the 28 March 2005 Nias $M_{\mathrm{W}} 8.7$ earthquake from continuous GPS data. Geophys Res Lett 33(7):L07307

Panet I, Pollitz F, Mikhailov V, Diament M, Banerjee P, Grijalva K (2010) Upper mantle rheology from GRACE and GPS postseismic deformation after the 2004 Sumatra-Andaman earthquake. Geochem Geophys Geosyst 11(6):258-273

Marone CJ, Scholtz CH, Bilham R (1991) On the mechanics of earthquake afterslip. J Geophys Res 96(B5):8441-8452

Savage JC, Prescott WH (1978) Asthenosphere readjustment and the earthquake cycle. J Geophys Res 83(B7):3369-3376

Shearer P, Bürgmann R (2010) Lessons learned from the 2004 Sumatra-Andaman megathrust rupture. Annu Rev Earth Planet Sci 38(1):103

Sieh K (2006) Sumatran megathrust earthquakes: from science to saving lives. Philos Trans R Soc Lond A 364(1845):1947-1963

Sieh K, Natawidjaja D (2000) Neotectonics of the Sumatran fault, Indonesia. J Geophys Res B 105(B12):28295-28326

Simons W, Socquet A, Vigny C, Ambrosius B, Haji Abu S, Promthong C, Subarya C, Sarsito D, Matheussen S, Morgan P (2007) A decade of GPS in Southeast Asia: resolving Sundaland motion and boundaries. J Geophys Res: Solid Earth (1978-2012) 112(B6):1-20

Sladen A, Avouac J, Meltzner AJ, Genrich JF, Galetzka JE, Sieh KE, Natawidjaja DH (2009) Source model of the 2008, $M_{\mathrm{W}}$ 7. 4, Simeulue, Indonesia earthquake-implication on the permanent nature of the Simeulue seismic barrier. In AGU Fall Meeting Abstracts, vol 1, p. 1926

Som SK, Choudhuri AR, Shivgotra V, Basir SR, Saha AK, Swamy MM (2011) Transtension to transpression: a study of strain evolution in Andaman Islands based on GPS measurements following Great Sumatra-Andaman earthquake, 2004. J Asian Earth Sci 42(1):38-50

Som SK, Saha AK, Shivgotra V (2014) Post-2004 mega-earthquake temporal velocity variation at Andaman Islands from GPS measurements. Nat Hazards 72(2):1051-1062

Subarya C, Chlieh M, Prawirodirdjo L, Avouac JP, Bock Y, Sieh K, Meltzner AJ, Natawidjaja DH, McCaffrey R (2006) Plateboundary deformation associated with the great Sumatra-Andaman earthquake. Nature 440(7080):46-51

Wei S, Helmberger D, Avouac JP (2013) Modeling the 2012 Wharton basin earthquakes off-Sumatra: complete lithospheric failure. J Geophys Res 118(7):3592-3609

Wessel P, Smith WH, Scharroo R, Luis J, Wobbe F (2013) Generic mapping tools: improved version released. Eos Trans Am Geophys Union 94(45):409-410

Yadav RK, Kundu B, Gahalaut K, Catherine J, Gahalaut VK, Ambikapthy A, Naidu MS (2013) Coseismic offsets due to the 11 April 2012 Indian Ocean earthquakes $\left(M_{\mathrm{W}} 8.6\right.$ and 8.2) derived from GPS measurements. Geophys Res Lett 40(13):3389-3393 